\title{
Association between Ala54Thr substitution of the fatty acid-binding protein 2 gene with insulin resistance and intra-abdominal fat thickness in Japanese men
}

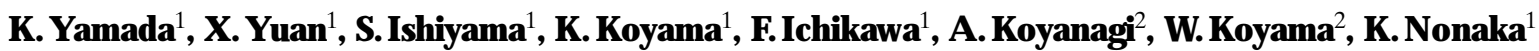 \\ ${ }^{1}$ Division of Endocrinology and Metabolism, Department of Medicine, Kurume University School of Medicine, Kurume, Japan \\ ${ }^{2}$ Kumamoto Red Cross Health Care Center, Kumamoto, Japan
}

Summary Alanine to threonine substitution at codon 54 of the fatty acid-binding protein 2 (FABP2) gene was recently shown to be associated with insulin resistance in Pima Indians. It has been hypothesized that the mutation may result in enhanced intestinal uptake of fatty acids, and thereby an impairment of insulin action. We analysed the association of the Ala54Thr substitution with insulin sensitivity and abdominal fat thickness in 395 Japanese men aged $50.5 \pm 8.8$ years (mean \pm SD) with a body mass index of $24.4 \pm 3.0 \mathrm{~kg} / \mathrm{m}^{2}$. The frequency of the Thr54 allele was 0.34 . Although the polymorphism was not significantly associated with diabetes or impaired glucose tolerance, subjects homozygous for the Thr54 allele had higher basal insulin levels. Analysis by homeostasis model assessment showed an association between the amino acid substitution and greater insulin resistance, and slightly higher beta-cell function. Oral glucose tolerance tests performed in 392 subjects without fasting hyperglycaemia showed higher 2-h insulin concentrations in individuals homozygous for the Thr54 allele when compared with heterozygotes or homozygotes for the Ala54 allele. No significant association was obtained between the polymorphism of the FABP2 gene and body mass index. However, ultrasound measurements of abdominal fat thickness revealed a greater accumulation of intra-abdominal fat in subjects homozygous for the Thr54 allele, whereas subcutaneous fat thickness was not associated with the polymorphism. These observations suggest that the Ala54Thr substitution in the FABP2 gene is associated with insulin resistance in Japanese men, and that visceral fat accumulation might be involved in the impaired insulin action associated with the substitution. [Diabetologia (1997) 40: 706-710]

Keywords Fatty acid-binding protein 2, intestinal fatty acid binding protein, insulin resistance, visceral fat.
Associations between non-insulin-dependent diabetes mellitus (NIDDM) and several genetic markers located on different chromosomes have been described. In the Pima Indians of Arizona who have

Received: 30 December 1996 and in revised form: 10 March 1997

Corresponding author: Dr. K. Yamada, Division of Endocrinology and Metabolism, Department of Medicine, Kurume University School of Medicine, 67 Asahimachi, Kurume 830, Japan

A bbreviations: NIDDM, Non-insulin-dependent diabetes mellitus; FABP2, fatty acid-binding protein 2; IFABP, intestinal fatty acid-binding protein; IGT, impaired glucose tolerance; HOMA, homeostasis model assessment; PCR, polymerase chain reaction. the highest prevalence of NIDDM in the world [1], insulin resistance shows familial aggregation and precedes the development of diabetes $[2,3]$. Sibling pair linkage analysis in Pima Indians has indicated a major gene associated with insulin resistance in a region on chromosome $4 \mathrm{q}$ near the fatty acid-binding protein 2 (FABP2) gene [4]. In Mexican-Americans, sibling-pair analysis showed significant association between the FABP2 gene locus and 2-h post-glucose challenge insulin levels [5]. The FABP2 gene which encodes intestinal fatty acid-binding protein (IFABP) has a polymorphism at codon 54. Recently, a substitution of alanine to threonine at codon 54 of the FABP2 gene was shown to be associated with insulin resistance in the Pima Indians [6]. IFABP is expressed in the epithelial cells of the small intestine villi, 
indicating that the protein has a role in fatty acid absorption and intracellular transportation $[7,8]$. It has been noted that elevated levels of serum fatty acids may have adverse effects on glucose metabolism due to increased uptake and intracellular oxidation of fatty acids [9-11]. Since the threonine-containing IFABP has a greater affinity for long chain fatty acids than alanine-containing IFABP in vitro [6], the substitution may increase the absorption of fatty acids, resulting in insulin resistance. Although obesity is a major factor impairing insulin sensitivity, the amino acid substitution in the FABP2 gene was not associated with body weight in the Pima Indians [6]. However, there is the possibility that the polymorphism may affect intraabdominal fat accumulation, because visceral adipose tissue may be associated with insulin resistance $[12,13]$.

The Japanese are one of the ethnic groups genetically susceptible to NIDDM. Furthermore, marked heterogeneity has been shown in the association of NIDDM with several candidate genes between the Japanese and other ethnic groups [14, 15]. A study using microsatellite DNA polymorphism has shown no significant linkage between the FABP2 gene locus and NIDDM or impaired glucose tolerance (IGT) in Japanese subjects [16]. However, the role of the Ala54Thr substitution in insulin resistance in the population remains to be determined. In this study we analysed the association between the Ala54Thr substitution of the FABP2 gene with insulin sensitivity and abdominal fat thickness in Japanese men.

\section{Subjects and methods}

We studied 395 Japanese men aged $50.5 \pm 8.8$ years (mean \pm SD) with a body mass index of $24.4 \pm 3.0 \mathrm{~kg} / \mathrm{m}^{2}$. All subjects were selected at random from people attending for health screening at the Kumamoto Red Cross Health Care Center. Blood samples were taken in the morning after an overnight fast. If fasting plasma glucose concentration was less than $7.8 \mathrm{mmol} / \mathrm{l}$, glucose tolerance was evaluated by administering 75 g glucose orally, and classified into normal, IGTand diabetes, on the basis of the World Health Organization criteria. Serum levels of insulin were measured by a luminescence enzymelinked immunosorbent assay (Sankyo, Tokyo, Japan). Beta-cell function and insulin resistance were assessed by the relationship between fasting glucose and insulin concentrations, analysed by homeostasis model assessment (HOMA) assuming that normal weight healthy subjects aged less than 35 years have $100 \%$ betacell function and an insulin resistance of 1 [17]. Subcutaneous and intra-abdominal fat thicknesses were measured by 14 operators using a standardized ultrasound technique $5 \mathrm{~cm}$ from the umbilicus on the line between the xiphoid process and the umbilicus in the supine position. Subcutaneous fat thickness and the distance between the internal face of the rectus abdominis muscle and the anterior wall of the aorta were measured by the method of Armellini et al. [18].

Genomic DNA was extracted from leukocytes by the phenol/chloroform method following incubation with proteinase K (Sigma, St. Louis, Mo., USA). Amplification of the FABP2
Table 1. Glucose tolerance and the FABP2 gene polymorphism at codon 54

\begin{tabular}{lrrrl}
\hline $\begin{array}{l}\text { Glucose } \\
\text { tolerance }\end{array}$ & Ala/Ala & \multicolumn{1}{l}{ Ala/Thr } & Thr/Thr & $\begin{array}{l}\text { Allele } \\
\text { frequency } \\
\text { of Thr54 }\end{array}$ \\
\hline Normal & $96(40.5 \%)$ & $115(48.5 \%)$ & $26(11.0 \%)$ & 0.35 \\
Impaired & $62(49.2 \%)$ & $48(38.1 \%)$ & $16(12.7 \%)$ & 0.32 \\
Diabetic & $14(43.8 \%)$ & $13(40.6 \%)$ & $5(15.6 \%)$ & 0.36 \\
Total & $172(43.5 \%)$ & $176(44.6 \%)$ & $47(11.9 \%)$ & 0.34 \\
\hline
\end{tabular}

gene sequence was performed by polymerase chain reaction (PCR) in a volume of $10 \mu \mathrm{l}$ containing $0.1 \mathrm{U}$ of Taq DNA polymerase (Takara, Otsu, Japan), $10 \mathrm{mmol} / \mathrm{l}$ Tris- $\mathrm{HCl} \mathrm{pH}$ $8.3,50 \mathrm{mmol} / \mathrm{l}$ of $\mathrm{KCl}, 1.5 \mathrm{mmol} / \mathrm{l}$ of $\mathrm{MgCl}_{2}, 100 \mu \mathrm{mol} / \mathrm{l}$ of dNTPs (Takara) with following primers: 5'-ACAGGTGTTAATATAGTGAAAAG-3' and 5'-TACCCTGAGTTCAGTTCCGTC-3'. After 35 cycles of 1 min at $94^{\circ} \mathrm{C}, 1 \mathrm{~min}$ at $58^{\circ} \mathrm{C}$ and $1 \mathrm{~min}$ at $72^{\circ} \mathrm{C}$, aliquots $(2 \mu \mathrm{l})$ of PCR products were analysed on $2 \%$ agarose gels (Nippongene, Toyama, Japan) to confirm the proper amplification. Then the amplified PCR products of $180 \mathrm{bp}$ were digested with the addition of $2 \mathrm{U}$ Hhal (Promega, Madison, Wis., USA) in $10 \mathrm{mmol} / \mathrm{l}$ Tris- $\mathrm{HCl} \mathrm{pH} 7.9,50 \mathrm{mmol} / \mathrm{l} \mathrm{NaCl}$, $10 \mathrm{mmol} / \mathrm{l} \mathrm{MgCl}$ and $1 \mathrm{mmol} / \mathrm{l}$ dithiothreitol. After an incubation at $37^{\circ} \mathrm{C}$ for $2 \mathrm{~h}$, the digested samples were separated by electrophoresis through $3 \%$ agarose gel and visualized by staining with ethidium bromide. PCR products having an intact Hhal site were cleaved into 99- and 81-bp fragments; the Ala54Thr substitution abolished the restriction site. All genotyping and data analysis were performed anonymously.

Statistical analysis. The results are presented as means \pm SD. Differences among the three-group means were estimated by the Kruskal-Wallis test. Student's unpaired t-tests were used to compare the means of two groups. Insulin values were logarithmically transformed before comparison by t-tests. The chisquare test was used to compare frequencies. A $p$ value of less than 0.05 was considered statistically significant.

\section{Results}

Of the 395 individuals, $172(43.5 \%)$ were Ala54 homozygotes, $47(11.9 \%)$ were Thr54 homozygotes, and $176(44.6 \%)$ were heterozygous for the polymorphism. The frequency of Thr54 allele was 0.34 . Three out of 395 subjects had fasting blood glucose levels over $7.8 \mathrm{mmol} / 1$; all of them were homozygous for the Ala54 allele. Oral glucose tolerance tests were performed in 392 subjects without fasting hyperglycaemia. Thirty-two out of the 395 subjects $(8.1 \%)$ proved to be diabetic and $126(31.9 \%)$ were classified as IGT (Table 1). No significant association was found between the Ala54Thr substitution and glucose tolerance $(p=0.38$, chi-square test). Fasting glucose values were not significantly different among the genotypes. However, subjects homozygous for the Thr54 allele showed higher basal insulin levels (Table 2). Analysis by HOMA showed significant association between the Thr54 allele and relative insulin resistance $(p=0.008$, Kruskal-Wallis test $)$. 
Table 2. The FABP2 gene polymorphism and insulin resistance estimated by HOMA

\begin{tabular}{lllll}
\hline Codon 54 & $\begin{array}{l}\text { Fasting plasma glucose } \\
(\mathrm{mmol} / \mathrm{l})\end{array}$ & $\begin{array}{l}\text { Basal insulin } \\
(\text { pmol/l) }\end{array}$ & $\begin{array}{l}\text { Relative beta-cell } \\
\text { function }\end{array}$ & $\begin{array}{l}\text { Relative insulin } \\
\text { resistance }\end{array}$ \\
\hline Ala/Ala $(\mathrm{n}=172)$ & $5.73 \pm 0.77$ & $34.0 \pm 17.3$ & $52.8 \pm 25.2$ & $1.48 \pm 0.85$ \\
Ala/Thr $(\mathrm{n}=176)$ & $5.69 \pm 0.64$ & $36.9 \pm 24.8$ & $57.9 \pm 35.3$ & $1.59 \pm 1.16^{\mathrm{c}}$ \\
Thr/Thr $(\mathrm{n}=47)$ & $5.87 \pm 0.66$ & $45.2 \pm 29.0^{\mathrm{b}}$ & $64.4 \pm 35.3^{\mathrm{c}}$ & $2.02 \pm 1.40^{\mathrm{b}}$ \\
& NS $^{\mathrm{a}}$ & $\mathrm{p}=0.023^{\mathrm{a}}$ & NS $^{\mathrm{a}}$ & $\mathrm{p}=0.008^{\mathrm{a}}$ \\
\hline
\end{tabular}

Data are mean \pm SD. NS, Not significant; ${ }^{a}$ Kruskal-Wallis test; ${ }^{b} p<0.05^{c} ; p<0.001$ vs Ala/Ala by t-test

Table 3. The FABP2 gene polymorphism and body fat distribution

\begin{tabular}{lllll}
\hline Codon 54 & $\begin{array}{l}\text { Body mass index } \\
\left(\mathrm{kg} / \mathrm{m}^{2}\right)\end{array}$ & $\begin{array}{l}\text { Subcutaneous fat } \\
\text { thickness }(\mathrm{mm})\end{array}$ & $\begin{array}{l}\text { Intra-abdominal fat } \\
\text { thickness }(\mathrm{mm})\end{array}$ & $\begin{array}{l}\text { Intra-abdominal fat/ } \\
\text { subcutaneous fat ratio }\end{array}$ \\
\hline Ala/Ala & $24.2 \pm 2.9$ & $12.0 \pm 4.1$ & $21.1 \pm 10.8$ & $1.86 \pm 0.98$ \\
Ala/Thr & $24.4 \pm 3.2$ & $11.9 \pm 4.0$ & $22.4 \pm 11.4^{\mathrm{b}}$ & $1.95 \pm 0.95^{\mathrm{c}}$ \\
Thr/Thr & $24.9 \pm 3.2$ & $11.5 \pm 3.3$ & $27.0 \pm 12.8^{\mathrm{c}}$ & $2.50 \pm 1.57^{\mathrm{d}}$ \\
& $\mathrm{NS}^{\mathrm{a}}$ & $\mathrm{NS}^{\mathrm{a}}$ & $\mathrm{p}=0.008^{\mathrm{a}}$ & $\mathrm{p}=0.002^{\mathrm{a}}$ \\
\hline
\end{tabular}

Mean \pm SD. NS, Not significant; ${ }^{a}$ Kruskal-Wallis test; ${ }^{b} p<0.05 ;{ }^{c} p<0.01 ;{ }^{d} p<0.001$ vs Ala/Ala by t-test

Homozygotes for the Thr54 allele had greater insulin resistance than homozygotes for the Ala54 allele $(p<0.001$, t-test). Insulin sensitivity was slightly reduced in the Ala54/Thr54 heterozygotes when compared with Ala54 homozygotes $(p=0.03)$. Furthermore, the analysis by HOMA suggests that the Ala54Thr substitution could be associated with greater beta-cell function. Thr54 homozygotes had higher relative beta-cell function than Ala54 homozygotes $(p=0.011$, t-test $)$, although the differences among the three groups were not statistically significant $(p=0.11$, Kruskal-Wallis test $)$.

The FABP2 gene polymorphism at codon 54 was not significantly associated with plasma glucose levels during the oral glucose tolerance tests, although Thr54 homozygotes showed slightly higher glucose levels than the Ala54 homozygotes and the heterozygotes (Fig. 1). However, insulin levels at $120 \mathrm{~min}$ were significantly associated with the FABP2 polymorphism ( $p=0.002$, Kruskal-Wallis test). Thr54 homozygotes had greater glucose-induced insulin response than Ala54 homozygotes, whereas the heterozygotes showed almost the same 2-h insulin levels as Ala54 homozygotes. However, the amino acid substitution was not significantly associated with blood pressure, serum total cholesterol, HDL-cholesterol, or triglyceride levels.

Next we analysed the association between the polymorphism and abdominal fat distribution measured by ultrasonography (Table 3 ). Relative insulin resistance measured by HOMA was correlated with intra-abdominal fat thickness $(r=0.413)$, and to a lesser extent, with abdominal subcutaneous fat thickness $(r=0.217)$. Beta-cell function was also correlated with subcutaneous and intra-abdominal fat thickness $(r=0.215$ and $r=0.291$, respectively). The thickness of intra-abdominal fat was significantly increased in subjects homozygous for the Thr54 allele
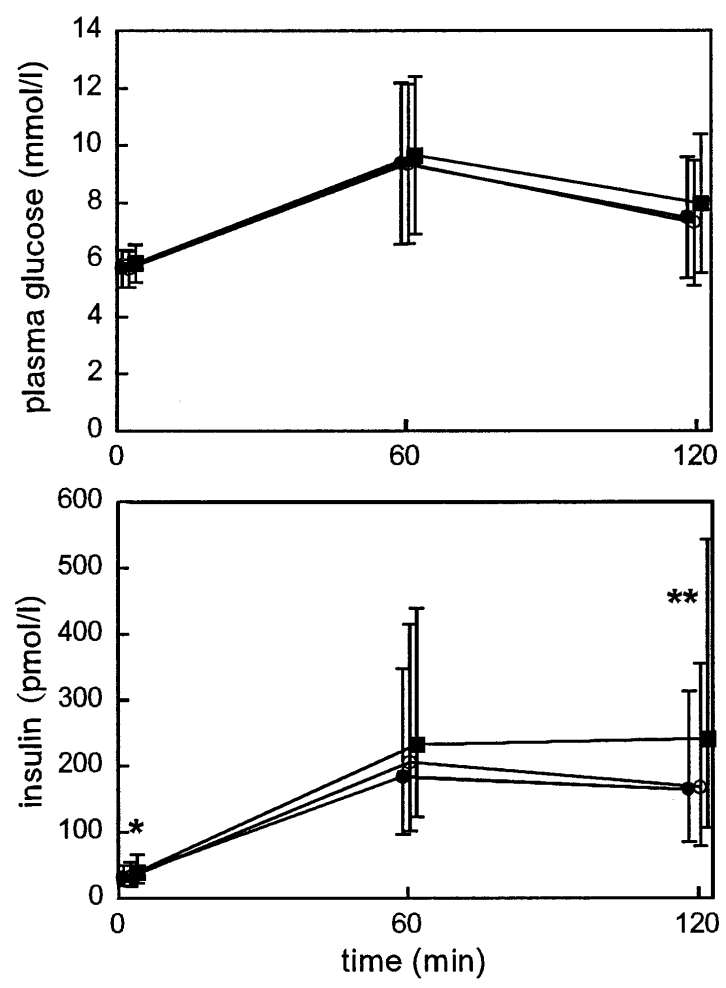

Fig. 1. Glucose (upper panel) and insulin (lower panel) levels during the $75 \mathrm{~g}$ oral glucose tolerance test. $\bullet$, Ala54/Ala54 homozygotes; O, Ala54/Thr54 heterozygotes; ם, Thr54/Thr54 homozygotes. Mean \pm SD. $p=0.017, * *, p=0.002$ by the Kruskal-Wallis test. Mean \pm SD of insulin levels were calculated after $\log ^{10}$ transformation

of the FABP2 gene, whereas subcutaneous fat thickness was not associated with the amino acid substitution. The ratio of intra-abdominal fat thickness/subcutaneous fat thickness was also high in the Thr54 homozygotes. In the heterozygous subjects, intra-abdominal fat thickness was only slightly increased when compared with Ala54 homozygotes. 


\section{Discussion}

This study showed that the Ala54Thr substitution in the FABP2 gene was associated with insulin resistance and intra-abdominal fat accumulation in the Japanese general population. The allelic frequency of Thr54 was 0.34 ; it was slightly higher than the ratios of 0.29 in Pimas and 0.31 in Caucasians [6]. No significant association was found between the Ala54Thr substitution and the prevalence of NIDDM or IGT. This is in accordance with a previous report showing no significant linkage between a polymorphic locus near the FABP2 gene and glucose tolerance in Japanese subjects [16]. Actually, in the Pima Indians, the Thr54 allele frequency was not significantly different between diabetic subjects and normal subjects, despite a marked association with insulin resistance [6]. In this study individuals homozygous for the Thr54 allele had higher basal and glucose-stimulated insulin levels than subjects lacking the allele. The most marked difference was found in insulin concentrations at $120 \mathrm{~min}$. The HOMA of fasting glucose and insulin could be affected by fluctuations of glucose and insulin levels. However, insulin resistance as estimated by HOMA was $36 \%$ greater in homozygotes for the Thr54 allele than homozygotes for the Ala54 allele $(p<0.001)$. Although the insulin resistance of Ala54/Thr54 heterozygotes showed intermediate levels between Ala54 homozygotes and Thr54 homozygotes, the difference between the heterozygotes and Ala54 homozygotes was minimal. Unexpectedly beta-cell function calculated by HOMA was slightly higher in subjects homozygous for the Thr54 allele. It is not known whether the augmented beta-cell function was secondary to the insulin resistance or independently resulted from the Ala54Thr substitution. The increased beta-cell function, however, apparently compensated for the insulin resistance in subjects with the amino acid substitution. This may be the reason why the polymorphism was not significantly associated with glucose tolerance.

The ultrasound measurement was used to estimate subcutaneous and intraabdominal adiposity. The measurement is suitable for large-scale studies, because it is convenient and less expensive when compared with computerized tomography [18-20]. The subjects homozygous for the Thr54 allele had greater measurements of ultrasound intra-abdominal fat thickness. It has been hypothesized that the higher affinity of Thr54 IFABP for fatty acids results in augmented intestinal absorption of fatty acids, and therefore, higher fat oxidation rates that inhibit insulin action [6]. Insulin resistance was positively correlated with intra-abdominal fat thickness. The intra-abdominal fat accumulation in subjects homozygous for the Thr54 allele could have resulted from the enhanced intestinal absorption of fatty acids. It is also possible that the visceral adiposity might be caused by the insulin resistance. Intra-abdominal fat accumulation has been shown to induce high fatty acid content in the portal circulation [21]. Our results suggest that, in addition to intestinal fatty acids, fatty acids released by intraabdominal adipose tissue might be involved in the insulin resistance associated with the Thr54 allele.

Insulin resistance is a major risk factor for NIDDM in Japanese as well as in Pima Indians and Caucasians. Considering the high prevalence of the Thr54 allele, the amino acid substitution may be commonly involved as one of poly-genes in the development of insulin resistance and NIDDM in Japanese subjects.

A cknowledgements. This work was partly supported by grantsin-aid for scientific research from Japanese Ministry of Education, Science and Culture. We thank Mr T.Fuke for technical assistance in the insulin assay.

\section{References}

1. Bennett PH, Burch TA, Miller M (1971) Diabetes mellitus in American (Pima) Indians. Lancet 2: 125-128

2. Lillioja S, Mott DM, Zawadzki JK et al. (1987) In vivo insulin action is a familial characteristic in nondiabetic Pima Indians. Diabetes 36: 1329-1335

3. Saad MF, Knowler WC, Pettitt DJ, Nelson RG, Charles MA, Bennett PH (1991) A two-step model for development of non-insulin dependent diabetes. Am J Med 90: 229-235

4. Prochazka M, Lillioja S, Tait JF et al. (1993) Linkage of chromosomal markers on $4 \mathrm{q}$ with a putative gene determining maximal insulin action in Pima Indians. Diabetes 42: 514-519

5. Mitchell BD, Kammerer CM, O'Connell P et al. (1995) Evidence for linkage of postchallenge insulin levels with intestinal fatty acid-binding protein (FABP2) in MexicanAmericans. Diabetes 44: 1046-1053

6. Baier LJ, Sacchettini JC, Knowler WC et al. (1995) An amino acid substitution in the human intestinal fatty acid binding protein is associated with increased fatty acid binding, increased fat oxidation, and insulin resistance. J Clin Invest 95: $1281-1287$

7. Lowe JB, Sacchettini JC, Laposata M, McQuillan JJ, Gordon JI (1987) Expression of rat intestinal fatty acidbinding protein in Escherichia coli. J Biol Chem 266: 17180-17186

8. Sweetser DA, Birkenmeier EH, Klisak IJ et al. (1987) The human and rodent intestinal fatty acid binding protein gene: a comparative analysis of their structure, expression, and linkage relationship. J Bio Chem 262: 16060-16071

9. Kelley D, Mokan M, Simoneau J-A, Mandarino LJ (1993) Interaction between glucose and free fatty acid metabolism in human skeletal muscle. J Clin Invest 92: 91-98

10. Randle PJ, Garland PB, Hales CN, Newsholme A (1963) The glucose fatty-acid cycle. Its role in insulin sensitivity and the metabolic disturbances of diabetes mellitus. Lancet I: 785-789

11. Felley CP, Felley EM, Van Melle GD, Frascarolo P, Jequier E, Felber J-P (1989) Impairment of glucose disposal by infusion of triglyceride in humans: role of glycemia. Am J Physiol 256: E747-E752 
12. Kissebah AH, Vydelingum N, Murray R et al. (1982) Relation of body fat distribution to metabolic complications of obesity. J Clin Endocrinol Metab 54: 254-260

13. Fujioka S, Matsuzawa Y, Tokunaga K, Tarui S (1987) Contribution of intraabdominal fat accumulation to the impairment of glucose and lipid metabolism in human obesity. Metabolism 36: 54-59

14. Kadowaki T, Kadowaki H, Yazaki Y (1993) Polymorphism of the glycogen synthase gene and non-insulin-dependent diabetes mellitus. N Engl J Med 328: 1568-1569

15. Fujisawa T, Ikegami H, Yamato E et al. (1995) A mutation in the glucagon receptor gene (Gly40Ser): heterogeneity in the association with diabetes mellitus. Diabetologia 38: 983-985

16. Yagi T, Nishi S, Hinata S-I, Murakami M, Yoshimi T (1996) A population association study of four candidate genes (hexokinase II, glucagon-like peptide-1 receptor, fatty acid binding protein-2, and apolipoprotein C-II) with type 2 diabetes and impaired glucose tolerance in Japanese subjects. Diabet Med 13: 902-907
17. Matthews DR, Hosker JP, Rudenski AS, Naylor BA, Treacher DF, Turner RC (1985) Homeostasis model assessment: insulin resistance and $\beta$-cell function from fasting glucose and insulin concentrations in man. Diabetologia 28: 412-419

18. Armellini F, Zamboni M, Robbi R et al. (1993) Total and intra-abdominal fat measurements by ultrasound and computerized tomography. Int J Obes 17: 209-214

19. Armellini F, Zamboni M, Castelli S et al. (1994) Measured and predicted total and visceral adipose tissue in women. Correlations with metabolic parameters. Int $\mathbf{J}$ Obes 18: 641-647

20. Tornaghi G, Raiteri R, Pozzato C et al. (1994) Anthropometric or ultrasonic measurements in assessment of visceral fat? A comparative study. Int J Obes 18: 771-775

21. Matsuzawa Y, Shimomura I, Nakamura T, Keno Y, Tokunaga K (1995) Pathophysiology and pathogenesis of visceral fat obesity. Ann N Y Acad Sci 748: 399-406 